\title{
THE PLACE OF POETIC TEXTS \\ IN TURKISH-LITERATURE EDUCATION AND THEIR REFLECTIONS ON SECONDARY SCHOOL TURKISH TEXTBOOKS
}

\author{
Hakan Yalap ${ }^{1 \mathrm{i}}$, \\ Sercan Demirgüneş², \\ Ahmet Akay ${ }^{3}$ \\ ${ }^{1}$ Associate Professor, \\ Nevsehir Haci Bektasi Veli University, \\ Turkey \\ ${ }^{2}$ Associate Professor, \\ Nigde Omer Halisdemir University, \\ Turkey \\ ${ }^{3}$ Turkish Teacher (MA), \\ Aksaray Cavdarlilar Middle School, \\ Turkey
}

\begin{abstract}
:
Literary texts have an important function in the education of Turkish and literature. It is certain that literary texts will steer the development of individuals in either lingual or emotion and value education. As for poetic texts involved in literary texts, they have a great role in increasing the aesthetic and artistic skills of their addressees, improving their vocabulary, making them aware of all the possibilities of the language, and increasing their perception of national and moral values. Due to all of these reasons, the poetic texts selected to be used in the Turkish textbooks are to meet some specific criteria. During the course of this study, the poetic texts in the Turkish textbooks recommended to be used in 2020-2021 school year favouring the principles of "harmony," "imaginary characteristics," "literary autonomy," and "suitability for children" constituting text characteristics have been evaluated by the experts in the literature, and some results have been achieved. It has been concluded that 20 of the 66 poetic texts analysed for this study are "good," 34 are "average," and 12 are "weak." In other words, 30\% of the 66 poetic texts are "good," $51 \%$ are "average," and 19\% are "weak." Based on these results, required sensitivity has not been shown to the poetic texts selected for textbooks. Considering the fact that secondary school students improve their language skills encountering quality texts, the poetic texts proposed to be used in the $5^{\text {th }}, 6^{\text {th }}, 7^{\text {th }}$, and $8^{\text {th }}$ grades have been stated at the end of the study.
\end{abstract}

Keywords: text, poetic text, poetic text characteristics, Turkish education

${ }^{i}$ Correspondence: email sdemirgunes@gmail.com 


\section{Introduction}

The quality of Turkish textbooks is very important since they enable students to effectively acquire the basic language skills (reading, writing, speaking, listening), and grammar that can be added to these skills. As a result of today in which knowledge reigns, even if the extreme use of technological tools is quite common, textbooks, one of the main materials of the Turkish lessons, still maintain their importance. As a result of the researches, it is a well-known fact that a lot of teachers have their classes with textbooks. According to the results of the research conducted by Özbay (2003: 13), most of the teachers $(94.44 \%)$ use Turkish textbooks as basic reference sources. Textbooks concrete the subjects taught in the classroom; meanwhile, texts and activities in them motivate the student for the lesson. Turkish textbooks are also one of the most important foundations for language teaching. Within this context, there must be a harmony from classroom environment to teacher, from syllabus to objectives, from teaching models to materials and textbooks to be used in the lessons. From all of these factors, in the sense of serving for the purpose, textbooks, and especially Turkish textbooks, fulfil an important duty. "Teaching Turkish is carried out through texts that have an important role in creating and improving the reading culture of an individual. In this sense, the quality of textbooks in which the selected texts take part becomes even more important" (İşeri, 2007: 61).

Texts are the works that reveal the niceties of a language. Amongst these texts, poetic texts are expected to be well-qualified based on its unique structure. The more qualified the poetic texts are (in terms of harmony, metre, rhythm, content), the more students enjoy these texts. Original poetic texts with high literary value are to be introduced to the students. Thus, students will witness the eloquence of Turkish. The fact that these texts contain harmony elements due to their nature may enable students to acquire the sense of harmony. In other saying, they provide the ability to look at the incidents and situations with an aesthetic eye. In brief, students acquire a broad perspective, and they become aware of what is different and valuable thanks to such texts.

Poetic texts are also an important tool for Turkish lessons to achieve their goals and objectives. In this respect, poetic texts are to be considered as the foundation of a house for Turkish lessons. In order to prevent the house from being demolished, its foundation, i.e. well-qualified poetic texts, is required to be strong. These qualities can be summarised as having high literary value, being strengthened with national and moral elements, enabling students to acquire aesthetic and artistic skills, being able to introduce Turkic and world culture to the students, enabling students to acquire reading skills.

\section{The Concept of Text and Text Types}

Looking at the word text, "considering that the fabric is formed, i.e. woven, when threads come together, it can be said that the concept of text is reached when the components making up the text are connected to one another" (Akbayır, 2013: 189). The Turkish word metin (text) is 
etymologically related to matn (من) from Arabic root mtn. It originates from a root meaning strong and durable in Arabic. In the literature, quite a lot of definitions for the concept of text are available. In the dictionary of Turkish Language Association, the following meanings are seen: "1. The whole of the words constituting a writing with features of form, expression and punctuation, tekst. 2. Printed or handwritten piece, tekst." In another definition, "Text is a meaningful, logical and related structure composed by all the languagebased structures" (Karatay, 2014: 70). It is a tool for expression and agreement addressing feelings, emotions, thoughts and information. "It can be said that the sentences constituting a text are within the limits of linguistics; however, as a tool for expression, text is more related to semantics"' (Aktaş, 2009: 189).

Even though it seems that it is the meaningful sentences that bring textuality to a text; in fact, a text has a different identity from the sentences. It is an idiosyncratic collection of language systems. "Not being able to be questioned as grammatical or ungrammatical like a sentence, or being a dynamic process of a language, text is not only a structure that consists of sentences, but also a unit that can be apprehended through sentence and extralinguistic elements apart from sentence" (Günay, 2013: 45-46). The sentences that constitute a text are meaningfully and consistently created by its writer, i.e. within a specific logical sequence.

Texts also bring about differences between multi text types in their explanations. Gündüz and Şimşek (2012: 48) divide texts into four as follows: narrative fictional texts, demonstrative dramatic texts, explanatory informative texts, and intuitive/emotional lyrical texts.

In the Turkish Course Curriculum (2018: 17), text types for primary and secondary schools, i.e. 1-8 grades, are divided into three as follows: informative texts, narrative texts, and poem.

\section{Poetic Text}

Turkish word manzum (poetic) derives from nazım (verse). As for the word nazım, it is a general name for the words made up of metric and rhyming verses (Karataş, 2004: 347). In the past, the word nazim was also used for poem.

"Poetic means metrically and rhymingly, even harmoniously, uttered words" (Karataş, 2004: 347). According to Turkish Language Association (2011: 1625), it is "1. Written in the form of poem. 2. Regular, regulated." As for Devellioğlu (2005: 718), he made such explanations: "1. Sequence, order, set. 2. Metric, rhyming words, poem."

In poetic works, "the auditorily aroused effect of the rhythm created by sounds and words while singing the verses, impressive metaphors, imaginary expression, and meaning density possessed by some words are remarkable (Sever, 2008: 146)." Since poetic texts facilitate reading and memorising, providing memorability, this type steps forward in language education. 


\section{Prosaic Text}

Before evaluating the concept of prosaic text, it is necessary to explain the word "nesr" which is the root of Turkish word mensur (prosaic). Arabic origined-word "nesr (nisâr)" is a verb with the meanings of "disperse, scatter, reproduce words," and a noun with the meanings of "regulated words apart from verse" in the dictionary (TDV İslam Ansiklopedisi, 9).

While conveying feelings, thoughts, and dreams through the means called language, it is essential to express them verbally or in writing, i.e. through verse or prose. With another definition, "it is a way of expressing ideas in prose without depending on the conditions such as metre and rhyme in general" (Geçgel, 2012: 118). In another definition, "for this reason, unlike a verse, neatly speaking and words in the natural talk are called prose" (Tâhirü' IMevlevî, 1984: 116). In the prosaically published texts, it is possible to say that the content is generally written depending on facts and truths. It is also possible to say that instructive and educational aspect of prosaic texts outweighs.

\section{What are the Differences between Poetic Texts and Prosaic Texts?}

It can be said that there are some differences between poetically and prosaically written texts in terms of expression forms, expression methods and language properties. These differences can be comprehensively stated as follows:

- While artistic concerns are at the forefront in poetic texts, educational and informative understanding is preferred in prosaic texts.

- "Poetry generally has a power that appeals to imagination, heart, soul, and creates enthusiasm. Poetry is an art that makes emotions speak. As for prose, it is known as a literary genre which is mostly unmetrical and unrhymed, written in sentences, and also sharing close relations with prose during some literary periods" (Tetik, 2020: 87).

- It can be said that poetic texts emerged earlier than prosaic texts.

- Poetic and prosaic texts are different from each other in terms of formal characteristics and content.

- In my opinion, the difference between poem and prose reminds me of the difference between looking and speaking" (Safa, 1937: 3). It is more likely for poetic texts to have many meanings with few words compared to prosaic texts.

- "While the words which are in the position of gemstones for prose symbolise a necklace strung on a thread based on some rules and measures, for prose, they symbolise shattered gemstones without depending on such a sequence order" (TDV İslam Ansiklopedisi, 6).

- Poem in which the portion of mind is limited is rather the product of imagination and being emotionally affected. As for prose, it is primarily based on mind, and the portion of others is less for it. While poem describes an unreal literary atmosphere using exaggeration, depiction, euphemism, imaginations and symbols, it is essential for objects and incidents to be described in prose (TDV İslam Ansiklopedisi, 6). 
- In "prose," none of the elements that are essential to create the style can be the subject under discussion. Poem and prose are two different architectures which depend on different rules having nothing to do with each other and rise in different fields with different sizes and shapes. "While the birth of prose is based on reason and logic, the birth of poem is a sacred and anonymous source, beyond comprehensibility, buried in the nights of secrets and unknowns, only whose enlightened waters' lights reflect on the horizons of the tangibles in season and out of season" (Haşim, 1928: 4). Strictly telling poem and prose apart, Haşim reasons prose out and emphasises that poem needs to be felt like a music.

- "Poem is a writing type that carries more aesthetic values and requires bigger concentration than prose" (Oğuzkan, 2001: 248). Poem possesses more beauty and aesthetics in itself, and compared to prose, it influences a person more deeply. Banarli (2005: 102) states how poem affect the soul of a person with these words: "Because, like every great art, poem, too, is a hard-to-get ore in reality. Whenever a poem is recited and heard, it needs to wing a person; however, it is expected to rise them to bright skies, not dark abysses. To the extent that it becomes the usage of the language with the most beautiful voice, a poem is beautiful to the extent that it rises a person spiritually and mentally. The one who hears the real poem needs to shudder as if they met God, and they need to feel the light waterfall moving inside them."

- Valéry likens prose to walking, and poem to dancing. While poem shows itself in a closed plane, prose develops openly and linearly (Korunan, 2011: 116).

\section{The Place and Importance of Poetic Texts in Turkish-Literature Education}

Poetic texts are one of the literary types written in the oldest form of literature, and inspired by emotions, thoughts and feelings. They are the voice of people's sufferings, griefs, longings, joys, and they have been guiding them throughout centuries. Therefore, poetic texts, especially poems, are the distilled products of the language, and it is possible to analyse them. In the light of these analyses, it becomes more important to scrutinise the place and importance of poetic texts in Turkish-Literature education. Published in 2019, "Turkish Course Curriculum" has been tried to be structured considering the expectations of the individual and the society. The society expects such abilities from individuals as critical and analytic thinking, questioning, solving problems, shaping Turkish culture, and having communication skills. In addition, the individuals who have been able to adopt reading culture can also have dynamics that can shape the society. In order to have reading culture, it is necessary to read and analyse the text with high literary value. When the Turkish Course Curriculum (2019: 35-50) is examined, such acquirements are seen in the secondary school texts books for poetic texts: 
Acquirements for Poetic Texts in the $5^{\text {th }}$ Grade

1- $\mathrm{S} / \mathrm{He}$ reads the text in accordance with the characteristics of the genre.

2- $\mathrm{S} / \mathrm{He}$ uses the reading strategies.

3- $\mathrm{S} / \mathrm{He}$ detects rhetorical figures in the text.

4- $\mathrm{S} / \mathrm{He}$ writes a poem.

5- S/He effectively uses body language while speaking.

\section{Acquirements for Poetic Texts in the $\mathbf{6}^{\text {th }}$ Grade}

1- S/He effectively uses body language while speaking.

2- $\mathrm{S} / \mathrm{He}$ reads the text in accordance with the characteristics of the genre.

3- $\mathrm{S} / \mathrm{He}$ detects rhetorical figures in the text.

4- S/He explains formal characteristics of the poem.

5- $\mathrm{S} / \mathrm{He}$ writes a poem.

\section{Acquirements for Poetic Texts in the $7^{\text {th }}$ Grade}

1- S/He effectively uses body language while speaking.

2- $\mathrm{S} / \mathrm{He}$ reads the text in accordance with the characteristics of the genre.

3- $\mathrm{S} / \mathrm{He}$ detects rhetorical figures in the text.

4- $\mathrm{S} / \mathrm{He}$ writes a poem.

5- $\mathrm{S} / \mathrm{He}$ uses the reading strategies.

6- S/He shares what s/he has written. (Students are encouraged to share what they have written on classroom or school pinboards or social media platforms and participate in poem and essay contests.)

\section{Acquirements for Poetic Texts in the $8^{\text {th }}$ Grade}

1- S/He effectively uses body language while speaking.

2- $\mathrm{S} / \mathrm{He}$ reads the text in accordance with the characteristics of the genre.

3- $\mathrm{S} / \mathrm{He}$ uses the reading strategies.

4- S/He detects rhetorical figures in the text.

5- $\mathrm{S} / \mathrm{He}$ writes a poem.

6- S/He shares what s/he has written. (Students are encouraged to share what they have written on classroom or school pinboards or social media platforms and participate in poem and essay contests.)

When these acquirements for poetic texts in secondary school textbooks are generally evaluated, it will be seen that the issue has not been sufficiently addressed. Since poetic texts, at the same time, effectively gather critical thinking, creativity, rhythm, and musicality, they are very important for Turkish education, and they have an 
important role for teachers to succeed. In this sense, the number of acquirements is to be increased and due importance is to be given concerning teaching poetic texts.

The place of poetic texts in Turkish education system, in fact, begins to be shaped when children have heard lullabies or poems before starting the school, and they skip to the educational environment acquiring some of these competences. In this respect, these texts help the child to form and develop the language by their nature. However, after examination, it will be seen that poetic texts are not valued enough in educational environments.

It is an important stage for Turkish education to utilise poetic texts in teaching listening, reading, writing, speaking, which makes up the four basic language skills, and in addition to these skills, grammar. For instance, when poetic texts are used in educational environments, they enable students to learn new words, increase their vocabulary, and then, bring on developing the basic language skills. They also increase the skills of reading poetic texts and verbalising power (oratory). During grammar teaching, too, poetic texts can be utilised. Because stepping out of classical grammar teaching both motivates the student and also allows different methods in the education. Unique musicality and harmony elements of poetic texts enable students to develop artistic and aesthetic skills. "Turkish and literature education is for the artistic and effective usage of the language" (Yalçın, Aytaş, 2002: 45). Thus, student reaches such powers as discovering the magic power of language, expressing their feelings and thoughts, and accordingly, acquiring artistic depth.

It is very important to meet some criteria to evaluate poetic texts in educational environments. First of all, teacher is to bring poetic text examples with high literary value to the classroom environment. "Due to having an important place in language learning and teaching, poetry is a field that every teacher needs to have in their repertoire" (Roe and Ross, 2006:40). However, in order to keep students' perception alive, teachers need to enter classroom environment, not always with the same methods, but with a book in which there are poetic texts that will attract students' attention, or other remarkably prepared materials (colourful, luminous, verbal stimuli); and thus, students will be motivated to learn the related subject. Teacher is to lead the student to analyse and interpret poetic texts; however, they are expected not to be dominant in this process. They should often give students voice and chance to interpret the texts. Because the student who has given voice will have developed a positive attitude towards such texts. The role model teacher will have presented the qualities of being a teacher by acting like that. A teacher is expected to take up the text seriously and stage it while being a role model. The teacher who does not feel the sense of the text will not be able to make the addressed student feel anything. It is very important to touch the student's heart, feelings, almost commune with them while processing poetic texts. During all of these educations, it is essential to make students completely adopt such elements as radif, rhyme, metre, alliteration, assonance for the success of the process.

During in-class activities for poetic texts, "memorising" practices can be done. Although memorising technique has a bad reputation, it is possible to create an interest 
and meaningful bond towards the text using the technique. Memorising poems promotes development of the memory, accompanied with attention, and also strengthens the memory. Thanks to memorising practices, student acquires the ability to speak in public, and gains self-confidence. Owing to this technique, they also focus themselves on the text, and experience the pleasure of the text. "It has been thought that students are made to comprehend words easily and more effective teaching will be provided through memorising poems" (İlhan, 2007: 47). During memorising practices, the usage of correct pronunciation, vocalising, toning, gestures and facial expressions should be elaborately taught. Sometimes, appropriate body movements can touch the hearts that words have not been able to touch.

Nowadays, in an environment where violence spreads to the whole society through films, cartoons, and animations, especially primary and secondary school students are deeply affected by this situation. Additionally, the generation lost or mechanised in the bottomless pits of the social media may be raised as insensitive individuals in the sense of emotions, thoughts and feelings. Using poetic texts while rehabilitating these students may also provide them with the ability to control their emotions, and mental relief. Tension created by the stress in the body may be minimised by reading or writing these texts. In the end, it is important for students to engage in poetic texts in terms of emotional integrity and finding their identities.

Emerging as the purpose of this study, it is necessary to examine the answer to the question "What should be the characteristics of poetic texts during teaching process?" in four main categories. These criteria have been grouped under four titles by Afacan (2013: 71):

\section{Harmony}

Harmony "is a term used in various science and art branches, which means that parts or elements constituting a whole harmonise one another within aesthetic measures. In the literature terminology, harmony, as a characteristic of the style, is the balance provided by putting words and sentences in a row in poem and prose almost creating a musical influence" (Macit, 2005: 8).

Poets try to create harmony in their works, and they benefit from some elements to bring harmony. These elements can be listed as metre, rhyme, radif, alliteration, and assonance. After those elements are integrated harmoniously, the musicality, i.e. harmony, of the text increases.

\subsection{Imaginary Characteristics}

Although image is used in many arts, it is one of the most important elements in poetic texts, and especially in poem. The Turkish word "imge" originates from Latin word "imago" with meanings like "imitation, copy." Then, "undergoing a semantic extension, it acquires meanings like "an image or concept that appears in the individual's mind" (Salman, 2004: 65). 
Image is indispensable for a poem. In fact, using image, it is possible to create original worlds. It is again the image bringing taste to the poem and raising the ability of abstract thinking to higher levels. However, it is essential to be careful about the dose of the image.

\subsection{Literary Autonomy}

Literary autonomy can be described as the purpose of the related poetic texts to exist in the textbooks. "The problem here is that an art branch is used as a "bespoke" tool, contrary to its own nature. Art, for sure, is not completely independent from social phenomena, or developments in the life. However, this does not mean that art takes on a task like conveying the reality in the form of a "report" " (Afacan, 2013: 74). It is a fact that poetic texts suitable for the theme are created in Turkish textbooks from time to time.

\subsection{Suitability for Children}

The principle of "suitability for children" is an important concept in terms of competence and effectiveness of poetic texts. "Along with its reality reflecting the nature, point of view, language and meaning universe, interest and needs of a child, a text is suitable for children to the extent that it prioritises literary criteria, and artistic sensibility" (Çer, 2016: 47). Considered from this perspective, poetic texts need to be selected to fulfil the individual's aesthetic needs and enrich their emotions, feelings, and universe of though, being away from didactic purposes.

\section{Methodology}

In the present study, the method of document analysis has been conducted. "Document analysis includes the analysis of written materials containing information on phenomena or incidents to be investigated" (Şimşek and Yıldırım, 2011: 187).

The poetic texts in Turkish textbooks for $5^{\text {th }}, 6^{\text {th }}, 7^{\text {th }}$, and $8^{\text {th }}$ grades accepted by Board of Education in the 2020-2021 school year have been analysed ${ }^{\text {ii }}$.

\subsection{Data Collection and Analysis}

The poetic texts from Turkish textbooks have been presented in tables within the specified qualifications after having been analysed by four literature experts. These qualifications have been determined as "harmony," "imaginary characteristics," "literary autonomy," and "suitability for children" specified by Afacan (2013: 71). Evaluated by the qualifications, the poetic texts have been determined as "weak(1)," "average(2)," and "good(3)," and after calculating the general average, the results have been shown in the table below with the title "poetry level."

During the process of analysing qualitative data, Miles \& Huberman (1994) reliability formula (Reliability $=$ Consensus) / (Consensus + Dissidence) has been utilised,

\footnotetext{
ii $5^{\text {th }}, 6^{\text {th }}$, and $7^{\text {th }}$ grade Turkish textbooks have private/different publishers from one another while $8^{\text {th }}$ grade
} Turkish textbook is from MEB Yayınları (Republic of Turkey, Ministry of National Education Publishing). 
and the agreement rate between researches has been found to be $86.7 \%$. As a result of this evaluation, it has been concluded that the study is reliable. Because the study is considered reliable if the agreement percentage is above $70 \%$.

\section{Findings and Interpretation}

\subsection{Analysis of the Poetic Texts in Accordance with the Determined Criteria}

Sixty six poetic texts in total in Turkish textbooks have been analysed by four literature experts in accordance with the factors of harmony, imaginary characteristics, literary autonomy, suitability for children as "weak(1)," "average(2)," and "good(3)," and analysis averages have been demonstrated in the last column of the tables as poetry level.

\subsection{Analysis of the Texts in the $5^{\text {th }}$ Grade Turkish Textbook in Accordance with the Criteria}

There are ten poetic texts in total in the $5^{\text {th }}$ grade Turkish textbook (Anittepe Publishing). Two of these poetic texts have been determined as "good," seven as "average," and four as "weak."

Table 2: Analysis of the Poetic Texts in the

$5^{\text {th }}$ Grade Turkish Textbook in Accordance with the Criteria

\begin{tabular}{|c|l|c|c|c|c|c|c|}
\hline S.N. & Text Title/Writer & Page & Harmony & $\begin{array}{c}\text { Imaginary } \\
\text { Characteristics }\end{array}$ & $\begin{array}{c}\text { Literary } \\
\text { Autonomy }\end{array}$ & $\begin{array}{c}\text { Suitability for } \\
\text { Children }\end{array}$ & $\begin{array}{c}\text { Poetry } \\
\text { Level }\end{array}$ \\
\hline 1 & $\begin{array}{l}\text { Memleket İsterim/ } \\
\text { Cahit Sıtkı Taranci }\end{array}$ & 10 & Good & Average & Good & Good & Good \\
\hline 2 & $\begin{array}{l}\text { Sevgi Ormani/ } \\
\text { Şükran Kurdakul }\end{array}$ & 36 & Average & Weak & Average & Average & Average \\
\hline 3 & $\begin{array}{l}\text { Mustafa Kemal' } \\
\text { in Kağnisı/ } \\
\text { Fazıl Hüsnü Dağlarca }\end{array}$ & Average & Average & Average & Average & Average \\
\hline 4 & $\begin{array}{l}\text { Çanakkale/ } \\
\text { Faruk Nafiz Çamlibel }\end{array}$ & 95 & Good & Good & Good & Good & Good \\
\hline 5 & $\begin{array}{l}\text { Tohumlar Fidana/ } \\
\text { Anonim }\end{array}$ & 99 & Weak & Average & Average & Average & Average \\
\hline 6 & $\begin{array}{l}\text { Yarın Gene Sabah Olacak/ } \\
\text { Nimetullah Hafiz }\end{array}$ & 104 & Average & Average & Average & Average & Average \\
\hline 7 & $\begin{array}{l}\text { Kilim/ } \\
\text { Fatih Kisaparmak }\end{array}$ & 143 & Weak & Weak & Weak & Average & Weak \\
\hline 8 & $\begin{array}{l}\text { Bilinçli Tüketici/ } \\
\text { Dursun Bulut }\end{array}$ & 159 & Average & Average & Average & Average & Average \\
\hline 9 & $\begin{array}{l}\text { Çiftçi ile Çocuklarl/ } \\
\text { Orhan Veli Kanik }\end{array}$ & $\begin{array}{l}\text { Yaşama Sevinci/ } \\
\text { Ali Riza Atasoy }\end{array}$ & Average & Average & Average & Average & Average \\
\hline 10
\end{tabular}

\subsection{Analysis of the Texts in the $6^{\text {th }}$ Grade Turkish Textbook in Accordance with the}

\section{Criteria}

There are twenty-nine poetic texts in total in the $6^{\text {th }}$ grade Turkish textbook. Eight of these poetic texts have been determined as "good," seventeen as "average," and one as "weak." 
Hakan Yalap, Sercan Demirgüneş, Ahmet Akay

THE PLACE OF POETIC TEXTS IN TURKISH-LITERATURE EDUCATION AND

THEIR REFLECTIONS ON SECONDARY SCHOOL TURKISH TEXTBOOKS

Table 3: Analysis of the Poetic Texts in the $6^{\text {th }}$ Grade Turkish Textbook in Accordance with the Criteria

\begin{tabular}{|c|c|c|c|c|c|c|c|}
\hline S.N. & Text Title/Writer & Page & Harmony & $\begin{array}{c}\text { Imaginary } \\
\text { Characteristics }\end{array}$ & $\begin{array}{c}\text { Literary } \\
\text { Autonomy }\end{array}$ & $\begin{array}{l}\text { Suitability for } \\
\text { Children }\end{array}$ & $\begin{array}{r}\text { Poetry } \\
\text { Level }\end{array}$ \\
\hline 1 & $\begin{array}{l}\text { Cırcır Böceği ile Karınca/ } \\
\text { Orhan Veli Kanik }\end{array}$ & 30 & Average & Average & Average & Average & Average \\
\hline 2 & $\begin{array}{l}\text { Kuşların Çektiği Kağnı/ } \\
\text { Fazıl Hüsnü Dağlarca }\end{array}$ & $42-43$ & Average & Average & Average & Average & Average \\
\hline 3 & $\begin{array}{l}\text { Mustafa Kemal'in Kağnısı/ } \\
\text { Fazıl Hüsnü Dağlarca }\end{array}$ & 45 & Average & Average & Average & Good & Average \\
\hline 4 & $\begin{array}{l}\text { Çanakkale/ } \\
\text { Faruk Nafiz Çamlibel }\end{array}$ & 51 & Good & Good & Good & Good & Good \\
\hline 5 & $\begin{array}{l}\text { Sakarya'nın Değeri/ } \\
\text { Nüzhet Erman }\end{array}$ & 63 & Average & Weak & Average & Average & Average \\
\hline 6 & $\begin{array}{l}\text { Atatürk Kurtuluş Savaşında/ } \\
\text { Cahit Külebi }\end{array}$ & 70 & Average & Average & Average & Average & Average \\
\hline 7 & $\begin{array}{l}\text { Uçurtma/ } \\
\text { Necdet Neydim }\end{array}$ & $74-75$ & Average & Weak & Weak & Average & Weak \\
\hline 8 & $\begin{array}{l}\text { Kırlara Gidiyorum/ } \\
\text { Cahit Zarifoğlu }\end{array}$ & 82 & Good & Good & Good & Good & Good \\
\hline 9 & $\begin{array}{l}\text { Kanatlanin Çocuklar/ } \\
\text { Yusuf Dursun }\end{array}$ & $91-92$ & Average & Average & Average & Average & Average \\
\hline 10 & $\begin{array}{l}\text { Karusel (Atlı Karınca)/ } \\
\text { Bahtiyar Vahapzade }\end{array}$ & 105 & Average & Average & Average & Average & Average \\
\hline 11 & $\begin{array}{l}\text { Zümrüdüankayı Arayan Çocuk/ } \\
\text { Ahmet Efe }\end{array}$ & 106 & Weak & Weak & Weak & Average & Weak \\
\hline 12 & $\begin{array}{l}\text { Sevgiyle/ } \\
\text { Ayla Çinaroğlu }\end{array}$ & 110 & Average & Average & Average & Average & Average \\
\hline 13 & $\begin{array}{l}\text { Yıldız Yağmuru/ } \\
\text { Ülkü Tamer }\end{array}$ & $\begin{array}{l}138- \\
139 \\
\end{array}$ & Good & Good & Good & Good & Good \\
\hline 14 & $\begin{array}{l}\text { Nineme Ninni/ } \\
\text { Ali Akbaş }\end{array}$ & 165 & Average & Weak & Average & Average & Average \\
\hline 15 & $\begin{array}{l}\text { Bir Gül Çocuk/ } \\
\text { Abdulkadir Budak }\end{array}$ & 167 & Average & Average & Average & Average & Average \\
\hline 16 & $\begin{array}{l}\text { Çocuklara Şiirler/ } \\
\text { Hasan Latif Yüce }\end{array}$ & 167 & Weak & Weak & Weak & Average & Weak \\
\hline 17 & $\begin{array}{l}\text { Çocuk ve Şiir/ } \\
\text { İsmail Uyaroğlu }\end{array}$ & 167 & Average & Average & Average & Average & Average \\
\hline 18 & $\begin{array}{l}\text { Bülbül Deresi Şiirleri/ } \\
\text { Gökhan Akçiçek }\end{array}$ & 167 & Average & Average & Average & Average & Average \\
\hline 19 & $\begin{array}{l}\text { Çile/ } \\
\text { Necip Fazıl Kisakürek }\end{array}$ & 167 & Good & Good & Good & Good & Good \\
\hline 20 & $\begin{array}{l}\text { Ozan/ } \\
\text { Zeynel Beksaç }\end{array}$ & 175 & Weak & Weak & Weak & Average & Weak \\
\hline 21 & $\begin{array}{l}\text { Halay/ } \\
\text { Ahmet Kutsi Tecer }\end{array}$ & 176 & Good & Average & Average & Average & Average \\
\hline 22 & $\begin{array}{l}\text { Mavi Portakal/ } \\
\text { Bedri Rahmi Eyüboğlu }\end{array}$ & $\begin{array}{l}187- \\
188 \\
\end{array}$ & Average & Average & Average & Average & Average \\
\hline 23 & $\begin{array}{l}\text { Uçak Yolculuğu/ } \\
\text { Cahit Külebi }\end{array}$ & 190 & Good & Good & Good & Good & Good \\
\hline 24 & $\begin{array}{l}\text { Çocuk ve Resim/ } \\
\text { Dilaver Cebeci }\end{array}$ & 214 & Average & Average & Average & Good & Average \\
\hline 25 & $\begin{array}{l}\text { Yürekler/ } \\
\text { Arif Nihat Asya }\end{array}$ & 231 & Good & Good & Good & Good & Good \\
\hline 26 & $\begin{array}{l}\text { Kurtla Köpek/ } \\
\text { Orhan Veli Kanik }\end{array}$ & $\begin{array}{c}250- \\
251\end{array}$ & Good & Good & Good & Good & Good \\
\hline 27 & $\begin{array}{l}\text { Vatan Sevgisini İçten Duyanlar/ } \\
\text { Aşık Veysel }\end{array}$ & 266 & Good & Good & Good & Good & Good \\
\hline 28 & $\begin{array}{l}\text { Alın Terinden Bir Deniz/ } \\
\text { Ali Akbaş }\end{array}$ & 274 & Average & Weak & Average & Average & Average \\
\hline 29 & $\begin{array}{l}\text { Çiftçinin Nasihati/ } \\
\text { İbrahim Alaattin Gövsa }\end{array}$ & 275 & Average & Average & Average & Good & Average \\
\hline
\end{tabular}




\subsection{Analysis of the Texts in the $7^{\text {th }}$ Grade Turkish Textbook in Accordance with the Criteria}

There are eleven poetic texts in total in the $7^{\text {th }}$ grade Turkish textbooks. Four of these poetic texts have been determined as "good," five as "average," and two as "weak."

Table 4: Analysis of the Poetic Texts in the

$7^{\text {th }}$ Grade Turkish Textbook in Accordance with the Criteria

\begin{tabular}{|c|c|c|c|c|c|c|c|}
\hline S.N. & Text Title/Writer & Page & Harmony & $\begin{array}{c}\text { Imaginary } \\
\text { Characteristics }\end{array}$ & $\begin{array}{l}\text { Literary } \\
\text { Autonomy }\end{array}$ & $\begin{array}{l}\text { Suitability for } \\
\text { Children }\end{array}$ & $\begin{array}{l}\text { Poetry } \\
\text { Level }\end{array}$ \\
\hline 1 & $\begin{array}{l}\text { Çalışkan Olmak/ } \\
\text { Atila Çakiroğlu }\end{array}$ & 16 & Average & Weak & Average & Average & Average \\
\hline 2 & $\begin{array}{l}\text { Baba, Bana Bir Şiir Bul/ } \\
\text { Mehmet Beşeri }\end{array}$ & 29 & Weak & Weak & Weak & Average & Weak \\
\hline 3 & $\begin{array}{l}\text { Bir Mustafa Kemal Vardı/ } \\
\text { Ümit Yaşar Oğuzcan }\end{array}$ & 61 & Average & Average & Average & Average & Average \\
\hline 4 & $\begin{array}{l}\text { Atatürk'ü Düşünürken/ } \\
\text { Cahit Sıtkı Taranci }\end{array}$ & 63 & Good & Good & Good & Good & Good \\
\hline 5 & $\begin{array}{l}\text { Yurt Türküsü/ } \\
\text { Vasfi Mahir Kocatürk }\end{array}$ & 117 & Good & Good & Good & Good & Good \\
\hline 6 & $\begin{array}{l}\text { Bir Başkadır Benim Memleketim/ } \\
\text { Fikret Şeneş }\end{array}$ & 119 & Average & Average & Average & Average & Average \\
\hline 7 & $\begin{array}{l}\text { Vatan/ } \\
\text { Yüksel İsak } \\
\end{array}$ & 128 & Weak & Weak & Weak & Average & Weak \\
\hline 8 & $\begin{array}{l}\text { Güz/ } \\
\text { Arif Nihat Asya }\end{array}$ & 148 & Good & Good & Good & Good & Good \\
\hline 9 & $\begin{array}{l}\text { Kır Çiçekleri/ } \\
\text { Hasan Latif Sariyüce }\end{array}$ & $\begin{array}{l}158- \\
159 \\
\end{array}$ & Average & Average & Average & Average & Average \\
\hline 10 & $\begin{array}{l}\text { Sazıma/ } \\
\text { Aşık Veysel Şatiroğlu }\end{array}$ & 173 & Good & Good & Good & Good & Good \\
\hline 11 & $\begin{array}{l}\text { A ğaç ve Sen/ } \\
\text { Hasan Ali Yücel }\end{array}$ & 200 & Average & Average & Average & Average & Average \\
\hline
\end{tabular}

\subsection{Analysis of the Texts in the $8^{\text {th }}$ Grade Turkish Textbook in Accordance with the Criteria}

There are sixteen poetic texts in total in the $8^{\text {th }}$ grade Turkish textbooks. Four of these poetic texts have been determined as "good," five as "average," and two as "weak."

Table 5: Analysis of the Poetic Texts in the

$8^{\text {th }}$ Grade Turkish Textbook in Accordance with the Criteria

\begin{tabular}{|c|l|c|c|c|c|c|c|}
\hline S.N. & Text Title/Writer & Page & Harmony & $\begin{array}{c}\text { Imaginary } \\
\text { Characteristics }\end{array}$ & $\begin{array}{c}\text { Literary } \\
\text { Autonomy }\end{array}$ & $\begin{array}{c}\text { Suitability for } \\
\text { Children }\end{array}$ & $\begin{array}{c}\text { Poetry } \\
\text { Level }\end{array}$ \\
\hline 1 & $\begin{array}{l}\text { İnsanla Güzel/ } \\
\text { İlhan Geçer }\end{array}$ & 28 & Average & Weak & Average & Average & Average \\
\hline 2 & $\begin{array}{l}\text { Atatürk'ü Gördüm Düşümde/ } \\
\text { A. Rıza Ergüven }\end{array}$ & 72 & Weak & Weak & Average & Weak & Weak \\
\hline 3 & $\begin{array}{l}\text { Bir Bayrak Rüzgâr Bekliyor/ } \\
\text { Arif Nihat Asya }\end{array}$ & $74-75$ & Good & Good & Good & Good & Good \\
\hline 4 & $\begin{array}{l}\text { Bayrağım/ } \\
\text { Hasan Ali Yücel }\end{array}$ & 77 & Good & Good & Good & Good & Good \\
\hline 5 & $\begin{array}{l}\text { Kaldırımlar/ } \\
\text { Necip Fazıl Kisakürek }\end{array}$ & $116-$ & Good & Good & Good & Good & Good \\
\hline 6 & $\begin{array}{l}\text { Azerbaycan-Türkiye/ } \\
\text { Bahtiyar Vahapzade }\end{array}$ & 121 & Average & Weak & Average & Average & Average \\
\hline Yrıyorum/ & 135 & Weak & Weak & Weak & Average & Weak \\
\hline
\end{tabular}




\begin{tabular}{|c|c|c|c|c|c|c|c|}
\hline 8 & $\begin{array}{l}\text { Türkiye/ } \\
\text { Attila İlhan }\end{array}$ & $\begin{array}{l}156- \\
157\end{array}$ & Average & Average & Average & Good & Average \\
\hline 9 & $\begin{array}{l}\text { İstanbul'la Hasbihal/ } \\
\text { Zeynel Beksaç }\end{array}$ & $\begin{array}{l}172- \\
173 \\
\end{array}$ & Weak & Weak & Weak & Average & Weak \\
\hline 10 & $\begin{array}{l}\text { Otuz Beş Yaş/ } \\
\text { Cahit Sttkı Taranci }\end{array}$ & 174 & Good & Good & Good & Good & Good \\
\hline 11 & $\begin{array}{l}\text { Vatan Sevgisini İçten Duyanlar/ } \\
\text { Aşı Veysel Şatiroğlu }\end{array}$ & 186 & Good & Good & Good & Good & Good \\
\hline 12 & $\begin{array}{l}\text { Uzun İnce Bir Yoldayım/ } \\
\text { Aşık Veysel Şatiroğlu }\end{array}$ & 189 & Good & Good & Good & Good & Good \\
\hline 13 & $\begin{array}{l}\text { İstanbul'u Dinliyorum/ } \\
\text { Orhan Veli Kanik }\end{array}$ & 212 & Good & Average & Average & Average & Average \\
\hline 14 & $\begin{array}{l}\text { Rüzgâr/ } \\
\text { Cahit Külebi }\end{array}$ & $\begin{array}{l}226- \\
227\end{array}$ & Average & Good & Average & Average & Average \\
\hline 15 & $\begin{array}{l}\text { Anadolu'da Bahar/ } \\
\text { Abdurrahim Karakoç }\end{array}$ & 248 & Good & Good & Good & Good & Good \\
\hline 16 & $\begin{array}{l}\text { Yaşamaya Dair/ } \\
\text { Nazım Hikmet Ran }\end{array}$ & $\begin{array}{r}262- \\
263 \\
\end{array}$ & Average & Good & Average & Average & Average \\
\hline
\end{tabular}

\section{Conclusion, Discussion, and Suggestions}

This study is based on the analysis of the poetic texts in $5^{\text {th }}, 6^{\text {th }}, 7^{\text {th }}$, and $8^{\text {th }}$ grade Turkish textbooks taught in 2020-2021 school year in accordance with the specified text criteria. 66 poetic texts in four Turkish textbooks, one of which was published by MEB, and the others by private publishing houses, have been analysed in accordance with the factors "harmony," "imaginary characteristics," "literary autonomy," and "suitability for children." Four literature experts have concluded that 20 of the 66 poetic texts are "good," 34 are "average," and 12 are "weak." In this sense, 30\% of the 66 poetic texts are in the level of "good," 51\% are "average," and 19\% are "weak."

As a result of the obtained findings, it has been seen that the texts in the database do not have the related criteria in the study in terms of the characteristics. The results of the study overlap the ones conducted by Solak and Yaylı (2009: 451). The findings obtained by this study shows that Turkish textbooks have been prepared without due care. Factors like ignoring the student's level, and the problems in the quality of the texts led to similar results. In the study conducted by Esin (2012: 122), it has been concluded that poems to be used in the Turkish textbooks need to be fit for the interests, ages, and levels of the students, the objectives specified in Turkish National Education Primary School Basic Law, and Turkish Education Programme, and capable of carrying out the target acquirements for the students. Considering their role, effect, importance in the process of education, and extensive usage in the educational environment, Turkish textbooks need to be available for teachers and students being free from errors and omissions. When poetic texts are imprecisely prepared, it may cause motivation loss in the students towards these texts. Considering the impact of these texts to enable students to acquire aesthetic and artistic skills, maintain emotional control, acquire harmony and rhythm skills, it is necessary to be more elaborate while selecting those texts for textbooks.

Considering the relationship between poetic texts and acquirements prepared by the Turkish Ministry of National Education, it is seen that they are not sufficiently associated, and the number of acquirements is insufficient. Even if it is said that they are 
associated with 5 different acquirements which they are thought to have direct and indirect relationship with poetic texts, this number is quite low compared to the importance of poetic texts.

$40(60 \%)$ of the 66 poetic texts analysed for this study are in the form of vers libre while $26(40 \%)$ are preferred to be metric. It will be useful to expose students to the texts in which such elements as radif, rhythm, metre, image, literary autonomy, harmony constituting the characteristics of poetic texts have been used in order to improve their lingual skills. Since the language of selected poetic texts is harmonious, and they have deep meanings, they differ from prose in terms of various rhetorical figures, and images. These elements have positive contributions to the students. In terms of raising students' ability of abstract thinking to higher levels, enabling them to look at incidents and situations with a critical, creative, and aesthetic perspective, poetic texts have a valuable place amongst all of the other text types.

Some works stand out in which texts have been selected contrary to "literary autonomy" which is one of the text characteristics of poetic texts. Ignoring other characteristics than having an instructive perspective in accordance with the theme in the textbooks, such texts reduce the effectiveness of Turkish textbooks. As Kaplan (2002: 246) mentioned, "instead of writing poems for the children, it is more appropriate to make them read the ones written for adults." Poetic texts written in a "childish" style will fail to fulfil many conditions in terms of characteristics. In this sense, it is necessary to elaborately prepare Turkish textbooks. In addition, unless required, poetic texts should not be shortened. 13 of the texts analysed for this study have been shortened. Shortening damages the integrity, and breaks the rhythm of the text. Additionally, while selecting more than one work by the people who are not widely accepted in the society, it is necessary to be careful about the characteristics of the text to be selected for the textbooks specified in the programme. Poetic texts with high literary value will provide a natural development in the student's world of thought and dream.

The aforementioned findings/results lead to the following suggestions:

a. It is necessary to select the poetic texts with the sensibility to present niceties and eloquence of Turkish.

b. It is necessary to consider the opinions of experts while selecting poetic texts.

c. Since teachers have a great responsibility in the process of transmitting poetic texts to the students, it is necessary to closely examine the stages of raising these teachers. It is necessary to add compulsory courses (text analysis, poem analysis, discourse analysis, etc.) in which poetic texts are discussed in every aspect for the Turkish and literature teaching departments.

d. Selecting the texts with high quality will bring the reading comprehension skills of the students.

e. It is necessary to give place to the works of the leading writers/poets as prioritised in the programme during the process of selecting poetic texts. 
f. Due to interdisciplinary working, not only in Turkish lessons, but also in the other lessons, it is necessary to utilise these texts. In conclusion, reading comprehension is a prerequisite for every lesson.

\section{Conflict of Interest Statement}

The authors declare no conflicts of interests.

\section{About the Authors}

Hakan Yalap is working as Associate Professor at Nevsehir Haci Bektasi Veli University in Turkey, Faculty of Education, Department of Turkish Education. His interests are Classic Turkish Literature, commentary, Turkish education, poetica.

Sercan Demirgüneş is working as Associate Professor at Nigde Omer Halisdemir University in Turkey, Faculty of Education, Department of Turkish Education. His interests are Turkish education, linguistics, grammar teaching, morphology, text linguistics.

Ahmet Akay is working as Turkish teacher at Aksaray Cavdarlilar Middle School in Turkey. His interests are Turkish education and poetica.

\section{References}

Afacan, A. (2013). Yazınsal Nitelik Açısından İlköğretimde Şiir ve Eğitimi, Doctoral Dissertation. Ankara University, Graduate School of Educational Sciences, Ankara.

Akbayır, S. (2007). Cümle ve metin bilgisi. Ankara: Pegem Akademi Yayınları.

Aktaş, Ş. (2009). Edebî metin ve özellikleri. Ataturk University Journal of Turkish Researches Institute. Prof. Dr. Hüseyin Ayan Özel Sayısı, 15(39), 187-200.

Banarlı, N. S. (2016). Edebiyat Sohbetleri. Istanbul: Kubbealtı Neşriyat.

Çer, E. (2016). Türkçe Öğretiminde Çocuğa Görelik İlkesine Uygun Edebiyat Yapıtlarının Önemi. İlköğretim Online, 15(4), 1399-1410.

Devellioğlu, F. (2005). Osmanlıca-Türkçe ansiklopedik lûgat. Ankara: Aydın Kitabevi.

Geçgel, H. (2012). Yeni bir nesir dili kurulmasında Ömer Seyfettin'in görüş ve önerileri. Journal of the Human and Social Science Researches, Volume: 1, Issue: 2.

Günay, V. D. (2013). Metin Bilgisi. (4 ${ }^{\text {th }}$ Edition). Istanbul: Papatya Yayıncllik.

Gündüz, O. and Şimşek, T. (2012). Anlatma Teknikleri II: Uygulamalı yazma eğitimi. Ankara: Grafiker Yayınları.

Haşim, A. (1928). “Şiir Hakkında Bazı Mülahazalar" (2 ${ }^{\text {nd }}$ Edition), Piyâle. Istanbul: Ikdam Matbaası.

WEB addresses: Retrieved August 20, 2021, from https://islamansiklopedisi.org.tr/ İlhan, N. (2007). Geçmişten Günümüze Sözlükçülük Geleneğgi ve Türk Dili Sözlükleri. Elazı̆̆: Manas Yayınları. 
İşeri, K. (2007). Altıncı sınıf Türkçe ders kitabının ilköğretim Türkçe programının amaçlarına uygunluğunun değerlendirilmesi. Dil Dergisi, 62, 136.

Kaplan, M. (2002). Sevgi ve İlim (Derlenmiş yazılar). İstanbul: Dergâh Yayınları.

Karatay, H. (2014). Okuma eğitimi kuram ve uygulama. Ankara: Pegem Akademi.

Korunan, O. (2011). Şiir ve Anlam. Beykent University Journal of Social Sciences (5),102-108.

Macit, M. (2005). Divan Şiirinde Âhenk Unsurları, Kap1 Publications, Istanbul.

MEB, (2019). Türkçe Dersi Öğretim Programı. Ankara: MEB Yayınları.

Miles, M. B., Huberman, A. M. (1994). Qualitative data analysis: An expanded sourcebook. Sage.

Oğuzkan, A. F. (2001). Çocuk Edebiyatı. Ankara: Anı Yayıncılık.

Özbay, M. (2003). Türkçe öğretiminde hedef-araç ilişkisinin ders kitabı örneğinde değerlendirilmesi. Journal of Turkology Research, 13, 59-69.

Roe, D. B. \& Ross, E. P. (2006). Integrating language arts through literature and thematic units. Boston, MA: Pearson.

Safa, P. (1937) "Şiir ve Nesir Farkı", Cumhuriyet, August 26, 1937, s.: 3.

Salman, Y. (2004). "İmge: Zor Yakalanır Bir Görselleştirme", Kitaplık Aylık Edebiyat Dergisi, 74, s.: 65-66.

Sever, S. (2008). Çocuk ve Edebiyat (4 ${ }^{\text {th }}$ Edition), Izmir: Tudem Yayınları.

Solak M. and Yaylı D. (2009). İlköğretim ikimci kademe Türkçe ders kitaplarının türler açısından incelenmesi. The Journal of International Social Research, Volume 2 / 9 Fall 2009.

Tâhirü'l-Mevlevî (1984). Edebiyat Lügatı, Istanbul: Enderun Kitabevi.

TDK. (2011). Büyük Türkçe Sözlük. Ankara: TDK.

Tetik K. and Yüksel G. (2020). Türk ve Rus Edebiyatında Süslü Nesir. Selçuk University Journal of Faculty of Letters, (44): 85-102.

Yalçın, A. and Aytaş G. (2002). Çocuk Edebiyatı, Akçă̆ Yayınları, Ankara.

Yıldırım, A. and Şimşek, H. (2011). Sosyal bilimlerde nitel araştırma yöntemleri (8 ${ }^{\text {th }}$ Edition). Ankara: Seçkin Yayıncılık.

Yıldırım, E. (2012). Şiirin Türkçe eğitimindeki işlevi ve ilköğretim ikinci kademe Türkçe ders kitaplarındaki şiirlerin yerinin incelenmesi. Yayımlanmamış yüksek lisans tezi. Pamukkale Üniversitesi, Sosyal Bilimler Enstitüsü, Türkçe Eğitimi Ana Bilim Dalı. 
Author(s) will retain the copyright of their published articles agreeing that a Creative Commons Attribution 4.0 International License (CC BY 4.0) terms will be applied to their work. Under the terms of this license, no permission is required from the author(s) or publisher for members of the community to copy, distribute, transmit or adapt the article content, providing a proper, prominent and unambiguous attribution to the authors in a manner that makes clear that the materials are being reused under permission of a Creative Commons License. Views, opinions and conclusions expressed in this research article are views, opinions and conclusions of the author(s). Open Access Publishing Group and European Journal of Education Studies shall not be responsible or answerable for any loss, damage or liability caused in relation to/arising out of conflicts of interest, copyright violations and inappropriate or inaccurate use of any kind content related or integrated into the research work. All the published works are meeting the Open Access Publishing requirements and can be freely accessed, shared, modified, distributed and used in educational, commercial and non-commercial purposes under a Creative Commons Attribution 4.0 International License (CC BY 4.0). 